\title{
ARTICLE
}

https://doi.org/10.1057/s41599-019-0258-1

\section{Is politics Aung San Suu Kyi's vocation?}

Mon Mon Myat ${ }^{1}$

\begin{abstract}
Western human rights activists saw Myanmar's prominent leader Aung San Suu Kyi as an embodiment of themselves, for which she was awarded the 1991 Nobel Peace Prize for her non-violent activism. But in the context of the 2017 Rohingya crisis, her international image seemingly changed, from that of Western saint to a demon, because she did not respond to the crisis in the way the Western community expected. Her moral authority was sharply questioned in the international media for her silence on the flight of more than 700,000 refugees from Myanmar to Bangladesh. This paper describes how a conundrum for a crusader of non-violence activism like Aung San Suu Kyi occurred and how a Nobel laureate faced ethical paradoxes between moral conviction and responsibility. It is also an effective way to develop the classical sociologist Max Weber's definition of a politician from his essay, "Politics as Vocation" to examine whether politics is Aung San Suu Kyi's vocation.
\end{abstract}

\footnotetext{
${ }^{1}$ Payap University, Chiang Mai, Thailand. Correspondence and requests for materials should be addressed to M.M.M. (email: monmonmyat@gmail.com)
} 


\section{Introduction}

"In their quest for democracy the people of Burma explore not only the political theories and practices of the world outside their country but also the spiritual and intellectual values that have given shape to their own environment." (Aung San Suu Kyi. and Aris, 2010, p. 178).

W hat does politics mean for Myanmar's prominent leader Aung San Suu Kyi? Politics mean for her "the sense of responsibility toward my people", she once told a journalist in an interview. Aung San Suu Kyi said her sense of duty was closely linked to love for her father, Aung San, the founder of modern Burma ${ }^{1}$ who was assassinated in 1947. Aung San Suu Kyi inherited the sense of responsibility as the political legacy of Aung San, "a man who put the interests of the country before his own needs" (Aung San Suu Kyi. and Aris, 2010, p. 37) as she described her father.

Daw Suu's ${ }^{2}$ moral legacy is rooted in Theravada Buddhism. Her popular concept "Freedom from Fear" is originally taken from Buddha's teaching of the four kinds of corruption. She wrote, "It is not power that corrupts but fear. Fear of losing power corrupts those who wield it and fear of the scourge of power corrupts those who are subject to it" (Aung San Suu Kyi. and Aris, 2010, p. 180). The Buddhist view of kingship is closely tied to her own Buddhist approach which she described in her essay, In Quest of Democracy: "the ruler must bear a high moral character to win the respect and trust of the people, to ensure their happiness and prosperity and to provide a proper example" (Aung San Suu Kyi. and Aris, 2010, p. 171). Buddhism plays a vital role in Myanmar politics since pre-colonial period. Using central Buddhist tenets such as the universal ruler, rulers claim divinity in order to uphold their position as the revered overlord of the masses (Tambiah, 1976, p. 41).

German sociologist Max Weber explained a similar approach about the nature of politics, ethics, responsibility and party in his classic essay "Politics as Vocation" written in 1919 after Germany's defeat in World War I. Like Aung San Suu Kyi, Weber saw the "profession" of politics as one embedded in particular ethics, which Weber called the "ethic of responsibility" and the "ethic of moral conviction." (Weber et al., 2015, p. 30)

In this context, Weber argued that the two ethics while crucial for a politician are tied together with a "sense of proportion". He writes that the passions of moral convictions must be balanced proportionately with rational execution of responsibility. Responsibility Weber writes requires a sense of objectivity. But passion is what is required for the commitment to a "cause" which embodies the god or demon who is the cause (Weber et al., 2015 , p. 180). But for Weber, as well as perhaps for Daw Suu, these are two qualities which are in tension with each other..." but which must be balanced within anyone that seeks to practice politics", which by Weber's classic definition requires the politician to operate the levers of power that are the monopoly over the use of coercive force. In other words, the task, always has the potential for violence (Weber et al., 2015, p. 212).

Weber elaborated "Every person who wants to become a politician, and especially a professional politician, has to be aware of the ethical paradoxes and his responsibilities for what and who he can become in the context of these pressures" (Weber et al., 2015 , p. 194). From this perspective, the idea of a politician like Aung San Suu Kyi also as a nonviolent activist seems like a contradiction. For Daw Suu, "Violence is totally contrary to the teaching of Buddhism. The good ruler vanquishes ill will with loving kindness, wickedness with virtue, parsimony with liberality, and falsehood with truth" (Aung San Suu Kyi. and Aris, 2010, p. 172). This contradicts what Weber wrote "The state is the only human Gemeinschaft which lays claim to the monopoly on the legitimated use of physical force" (Weber et al., 2015, p. 136). Though Daw Suu might want to avoid dealing with violence, she needs to take responsibility for the act of the state's physical force when she becomes a stateswoman.

This is why Weber views the ethical practice of politics as being almost an impossibility, concluding:

Only the person who is sure that he will not despair when the world, from his standpoint of view, is too simpleminded and wicked to accept what he has to offer, and only the person is able to say "In Spite of it All" has a calling for the profession of Politics! (Weber et al., 2015, p. 198).

\section{A responsible Myanmar politician: operating the levers of} power. Aung San Suu Kyi's source of ethic of responsibility originated from her father, a military leader of resistance to British colonial rule, and founder of modern Myanmar who was assassinated in 1947. She admitted that it was her father who inspired her to take part in politics. "When I first decided to take part in the movement for democracy, it was out of a sense of duty rather than anything else. On the other hand, my sense of duty was very closely linked to my love for my father. I could not separate it from the love for my country, and therefore, from the sense of responsibility toward my people" (Houtman, 1999, p. 16).

She describes about Aung San in her hagiographic essay $M y$ Father:

Aung San's appeal was not so much to extremists as to the great majority of ordinary citizens who wished to pursue their own lives in peace and prosperity under a leader they could trust and respect. In him they saw that leader, a man who put the interests of the country before his own needs, who remained poor and unassuming at the height of his power, who accepted the responsibilities of leadership without hankering after the privileges, and who, for all his political acumen and powers of statecraft, retained at the core of his being a deep simplicity (Aung San Suu Kyi. and Aris, 2010, p. 37).

When Aung San was assassinated, Aung San Suu Kyi was two years old. She learned about her father from family members, friends of her father and a few written and printed materials she gathered. Daw Suu often described her father's political philosophy in her speeches. "My father is very disciplined person. He loves to be a soldier as he liked comradeship but when the country needed him to be a politician, he immediately left the army and entered into politics as a civilian" (Suu Kyi, 2016, p. 129).

Like father like daughter, Aung San Suu Kyi entered into Myanmar politics in 1988 when the country needed her to lead the democracy movement. She left her family in the UK and she left her academic life when she decided to embark on the path of democracy, which her father wasn't able to complete.

In her first speech to a mass rally at the Shwedagon Pagoda in August 1988, Aung San Suu Kyi said:

A number of people are saying that since I have spent most of my time abroad and am married to a foreigner I could not be familiar with the ramifications of this country's politics. I wish to speak from this platform very frankly and openly to the people. It is true that I have lived abroad. It is also true that I am married to a foreigner. These facts have never interfered and will never interfere with or lessen my love and devotion for my country by any measure or degree (Aung San Suu Kyi. and Aris, 2010, p. 193). 
Aung San Suu Kyi left Myanmar when she was 15. She studied philosophy, politics and economics at the University of Oxford. She finally came back to Myanmar to look after her ill mother in 1988. While there she took part in the 1988 pro-democracy uprising as a daughter of General Aung San. She had never experienced political struggle in her life before then. That was the beginning of her life as a politician.

In the early '70s when Aung San Suu Kyi returned to Myanmar on a family visit, she was asked whether she had "any interest in politics" and she answered "if ever I was going to get involved with Burmese politics, it would only be from inside the country" (Transcript of ASSK interview, n.d.). Since getting into politics in Myanmar she never abandoned the movement although the ruling military generals tried to force her departure by limiting her family visits.

In her book Freedom from Fear, she wrote:

The Burmese people, who have had no access to sophisticated academic material, got to the heart of the matter by turning to the words of the Buddha on the four causes of decline and decay: failure to recover that which had been lost, omission to repair that which had been damaged, disregard of the need for reasonable economy, and the elevation to leadership of men without morality and learning. (Aung San Suu Kyi. and Aris, 2010, p. 168).

Thus from 1990 to 2010 she was, in German sociologist Max Weber's term, "a voluntary politician"-while spending 15 years under house arrest, pondering the nature of politics in Myanmar.

Nobel peace prize winning activist. Aung San Suu Kyi has made perhaps a unique shift from a voluntary politician to a professional politician in her career, and for that reason her case is interesting to study from the lens of Max Weber's definition of a politician. As a leader of a political party, National League for Democracy (NLD), she emerged from the massive "people power" demonstrations in 1988 where she helped organize nonviolent actions. In doing this, she cited Henry David Thoreau's concept, "On the Duty of Civil Disobedience", Gandhi's philosophy of Non-violence, the Universal Declaration of Human Rights, and her own "Freedom from Fear" doctrine in her public speeches and conversations.

Aung San Suu Kyi wrote about nonviolent actions in her essay, In Quest of Democracy during the 1990s and 2000s:

The institutions and practices of democracy provide ways and means by which such changes could be effected without recourse to violence. But change is anathema to authoritarianism, which will tolerate no deviation from rigid policies. Democracy acknowledges the right to differ, as well as the duty to settle differences peacefully. (Aung San Suu Kyi. and Aris, 2010, p. 176).

Daw Suu and her comrades founded a political party, National League for Democracy (NLD), in September 1988 soon after the pro-democracy uprising ended with a bloody military coup. As Daw Suu's popularity became a threat to the power of the authoritarian military regime, Myanmar's generals put her under house arrest in 1989. Although she was under house arrest, millions of supporters voted for her party in the 1990 election, and her NLD party won a landslide victory. But military leaders did not hand over government administration to the NLD while keeping Aung San Suu Kyi under house arrest, and in fact held power until 2010.

At the beginning of her house arrest, Aung San Suu Kyi was given the 1991 Nobel Peace Prize "for her nonviolent struggle for democracy and human rights". But in 2015, her position changed suddenly, when the NLD was thrust to prominence as the winner of another election, which forced her into an awkward ruling arrangement with the military government, which had kept her, confined for so long. So in Weber's terms, she would no longer be simply the passionate advocate of moral convictions. She now would operate the levers of coercive power that is government, and had the responsibility to rule for the benefit of the country, in a context where a wrong move could lead to a coup or military action. In this context the "proportion" between the ethics of responsibility and moral conviction that Weber wrote of suddenly became central.

Western Icon-activist. To understand how deep such values are in shaping values and ethics, Weber describes how Gemeinschaftbased associations (Stände) are rooted in the "identities" that fascinate English-speaking sociologists today. People sharing a stand/status recognize each other as "us" and everyone else as "them" who are those outside the group. (Weber et al., 2015, p. 3) And here lies the tension between how Aung San Suu Kyi is perceived in the West as a nonviolent democracy icon and human rights activist, and among the Bamar ${ }^{3}$ people as a symbol of the national essence which springs from her father General Aung San.

Aung San Suu Kyi also assumed military generals saw her differently. She told the US Congressman Bill Richardson during his first visit to her in 1994, "If they are afraid of something, if they are serious in thinking I have a neocolonialist bogey behind me, then they need to talk to me. My loyalties are to Burma. But I for one will not abuse other countries and the international community to prove my love" ("Transcript of ASSK interview", n.d.).

But meanwhile Aung San Suu Kyi was considered for the West a democracy icon and human rights activist, with a status (stand) identity rooted in the Nobel Peace Prize. As a result, she was never considered first as a politician who wields an ethic of responsibility for her nation's well-being, especially the preservation of the Gemeinschaft-based values of those who elevated her to her position. But according to a Western narrative popularized in the international press (and her Nobel citation) she is only a moral leader and therefore unsullied by the use of the violent power a politician inherently possesses.

In the Western press there was little appreciation for Aung San Suu Kyi's double identity. Since the 1990 s, she was portrayed as a democracy and human rights icon in international media. She was described as Asia's Mandela, and a freedom fighter. No mention was made of her role as the leader of an insurgent political party, the NLD, the long-standing political party that fought against military rule since the beginning of 1989. It was in this context that the Western press saw her in coming decades as she was placed under house arrest, and even as she began to win by-elections in 2012, and finally following her party's landslide victory in the November 2015. In all this time, she remained a romantic figure, an apostle for the human rights dreams of the West.

But the hagiographic view quickly changed in 2017 following the Rohingya crisis, as the New Yorker's "ignoble laureate" emerged due to what they perceived as her silence on the flight of more than 700,000 refugees from Myanmar to Bangladesh. Her moral authority was sharply questioned in the international community. An opinion piece written in the Washington Post newspaper lashed out at her for abdicating her role as a pure activist, and taking on the mantle of just another boorish politician:

We expect President Trump to be a boor. We expect the Putins, the Xis, the Erdogans to brutalize their own people. 
But there is something uniquely awful about a Nobel Peace Prize laureate acting as an enabler of the murder and displacement of an entire community (Caryl, 2017).

Others called for her to be stripped of her Nobel Peace Prize for her inaction in 2017. Oddly, among the Nobel Peace Prize Laureates, more than the half are statesmen or politicians including four American Presidents Barack Obama, Jimmy Carter, Woodrow Wilson, and Theodore Roosevelt. Henry Kissinger as US Secretary of State won the award for his work ending the Vietnam War, and then went on to engineer a violent coup in Chile, and extra-judicial killings in Latin America. But unlike other Nobel Laureates, the expectation of the international community toward Aung San Suu Kyi was different. The reasoning seemed to be that her moral authority "for her nonviolent struggle for democracy and human rights" was to extend to her political role as well. Her ethic of moral convictions became a great concern for those who envisioned Aung San Suu Kyi as a saint in "the modern, mass, visual-image-led perception of heroes and heroines" (Wintle, 2008, p. 355). In this context, her silence over the 2017 Rohingya exodus and military operation in Rakhine State in Myanmar seemingly broke their Western hearts.

In this context, her nonviolent principles were questioned because of what activists saw as her failure to stop military action against Rohingya, the minority Muslim group in Myanmar whose citizenship status and right to exist in Myanmar had become important. And while activists saw this as a moral failure, or what they called a failure of "political will," from Weber's viewpoint there is in fact a different way to look at her "inaction" regarding the Rohingya which takes into context her responsibility for the wielding of what state power she does possess. This is why Weber said, "every politician engages with diabolical powers, which lurk in every kind of violence" (Weber et al., 2015, p. 194).

The Rohingya narrative was extensively highlighted in the international media following the latest refugee exodus in late August 2017 where the international community played a significant role in making the name Rohingya globally recognized. The author Jacques P. Leider highlights the formation of Rohingya identity by the Western community:

The recognition that the term enjoys presently, though very recent, has had a major impact beyond simply giving the international public a greater awareness of the communal strife. Its conventional use by the media and by international organizations puts pressure on all the Muslims in Rakhine, especially when they leave the country, to define themselves exclusively as "Rohingyas" for the simple reason that outside of Myanmar, the term has a high value in terms of name recognition. More than that, for Western media as well as members of international organizations who are in charge of humanitarian missions and more particularly for those who do advocacy, the use of the term "Rohingya" has become a matter of political correctness. Not calling the Muslims "Rohingya" may be considered, by many activists, as the denial of their self-acclaimed ethno-religious identity and, by extension, a virtual rejection of claims on citizenship (Egreteau, R., \& Robinne, F. (2015). p. 157).

The international community, including media and humanitarian organizations, framed this view using the fundamental tenets of liberalism concerning individuals and the expression of their preferences. Concerning individual rights and freedom of expression, the international community legitimated Rohingya identity. In the latest UN Security Resolution, Independent International Fact-Finding Mission called for "acknowledgment of the arbitrary deprivation of nationality of the Rohingya community and restore their citizenship rights." Whether Myanmar's citizenship law accepted it or not, Rohingya became a globally recognized identity.

Aung San Suu Kyi has been condemned by international community for not speaking up about the flight of Rohingya refugees, and was asked to give up Nobel Peace Prize because it was believed she betrayed the values, morality, and meanings attributed to the prize by the Western activists. For the Western activists, there was a cognitive dissonance between the actions of the politician Aung San Suu Kyi, and the activist Aung San Suu Kyi. In effect, in 2017 Aung San Suu Kyi as a political leader of Myanmar was forced to resolve two dissonances: That of the West which saw her as a human rights activist, and that of the Bamar majority of Myanmar which saw her as a protector of their rights and prerogatives as citizens against foreign interlopers such as the Bengali or the Rohingya. It is in the context of the Myanmar army's expulsion of the Rohingya in 2017 that international critics blamed their icon, State Counselor Aung San Suu Kyi, for the crackdown on the Rohingya.

Aung San Suu Kyi sought to explain the situation in her country by relying on one of the catchwords that had made her famous: "fear". In an interview given in October 2013 she said, "This problem arose last year, and this is to do with fear on both sides. The fear is not just on the side of the Muslims but also on the side of the Buddhists as well. Muslims have been targeted but also Buddhists have been subjected to violence....Global Muslim power is very great and certainly, that is a perception in many parts of the world and in our country as well" (Siddique, 2013). These statements reflect the deep-seated antagonism between the Buddhist and Muslim communities of Myanmar, the latter mainly of Indian origin, steaming back to the colonial period. Aung San Suu Kyi's remarks point to the complex mix of political, economic, and religious factors that-unnoticed by many foreign observers for a long time-contributed to the outbreak of violence in 2012 and 2013 both in Rakhine State and in central Myanmar (Zollner et al., 2018, p. 236).

\section{Activism as vocation}

Since Aung San Suu Kyi has been working as State Counselor and Foreign Minister, her popularity as a charismatic leader diminished. Not only the Western community, but many local people criticize her silence over several issues including the on-going civil war, assassination of a prominent NLD legal adviser, religious conflict in the country's Western part, and other problems related to actions by the military.

The fading of charisma implies that, if one looks at the whole process of change, the consequences of individual actions diminish. And of all the forces repressing such individual action, rational discipline is, in the long run, the most compelling (Weber et al., 2015, p. 62).

Activism and moral conviction. Weber in defining the ethic of moral conviction implies that for such a person to remain an activist, they must remain above the political fray:

A person who wants to act accordingly to the ethic of Gospel, should not join the "yellow unions" (Unions organized by the company) and participate in strikes, because strikes are coercive. First and foremost, however, he should not talk "revolution." Because the ethic [of love] does certainly not teach that civil war is the only legitimate war. (Weber et al., 2015, p. 187).

In 2012 after her release from house arrest, Aung San Suu Kyi was finally able to deliver her Nobel lecture highlighting 
humanity, democracy and human rights beyond national borders in the Oslo City Hall, in Norway.

She read the passages below and spoke as the activist who had been awarded the prize. She explained why she is fighting for human rights and democracy.

...... it is essential, if man is not to be compelled to have recourse, as a last resort, to rebellion against tyranny and oppression, that human rights should be protected by the rule of law...

If I am asked why I am fighting for human rights in Myanmar the above passages will provide the answer. If I am asked why I am fighting for democracy in Myanmar, it is because I believe that democratic institutions and practices are necessary for the guarantee of human rights.

(The Nobel Prize, 2012).

Such beautiful sentiments are those of the moral convictions of an activist who does not have power. This is before she accepted the responsibility of the "absolute politician" though. As an activist she practiced the "duty to truthfulness," and it is indispensible for "absolute ethics", but she didn't have to take responsibility for the consequences of what she said. But whatever she says today as a politician has consequences because she has to take full responsibility for the country as Minister of Foreign Affairs as well as the odd position of State Counselor.

Activism and responsibility. In 2011, Aung San Suu Kyi said during the interview with the author:

Nonviolence is a basic principle. Based on that principle, there are different ways. As I have often been asked this question, I have often answered using Gandhiji's saying: 'Nonviolence requires more courage, more determination and it is harder than using a violent way.' Although it is harder, it can go further. If we use the violent way, we might reach our goal quickly but there will be many wounds among the people and for the country. It will take a long time to cure those wounds. But if we use a nonviolent way, it will take time to reach our goal but the country's rehabilitation won't take a long time. If we use the wrong way, we may miss our goal (Myat, 2011).

Unstated, though is the limitation of such activism in the context of governance in a non-liberal military dictatorship. Or as Weber writes "The disciple of Christ does the right thing but the outcomes is left to the discretion of God." In other words, the simple disciple of Christ has no "responsibility" to manage the state, and has the luxury, as an activist does, to insist on moral purity.

As a politician Aung San Suu Kyi also must deal with the ethics of responsibility because she is, as clearly stated herself, a politician, that is "the one who is responsible for the foreseeable consequences of one's actions" as Weber wrote. (Weber et al., 2015 , p. 188) Weber's words illustrate the occasional impossibility of the politician's task, which involves both ethics of responsibility and of moral responsibility. But Weber said "the ethic of moral convictions [Gesinnungsethik] and ethic of responsibility [Verantwortungsethik] are not complete opposites. They rather complement each other because together they constitute a true human being, and the one who is able to have politics as a vocation."

\section{Politics as vocation}

What is politics? Max Weber said:
The term 'Politics' is a very wide one and encompasses many kinds of leadership functions. One talks of foreign currency politics of private banks, of the interest rate politics of the Reichsbank regarding bills of exchange, of union politics during a strike, a city or town's school politics, and a club president's politics of leadership. Finally, one talks even of the clever politics of a wife when she attempt to lead her husband" (Weber et al., 2015, p. 135).

Or as Aung San Suu Kyi spoke during a public rally, "Going to the market everyday is related to politics, when a housewife goes to the market and faces commodity price hike, that's politics. If you find out why the price is increased, that's politics too" (Suu Kyi, 2016, p. 131). In one of her public speeches after she was released from house arrest, she said, "We can't stay away from politics. That's why you should try to learn politics. If you are not interested in what is related to you, it will strike you later" (Suu Kyi, 2016, p. 132).

It is just the same as her father Aung San's philosophy of politics. "Politics means our everyday life. In other words politics is human affairs. It is how we eat, sleep, work and live, with which politics is concerned. We may not think about politics but politics always connects with us" ("Aung San of Burma," n.d.). Both of them talks about "cause politician" as Weber said "we all are 'cause politician' when we hand in our ballot paper or when we express any similar opinion by applauding or protesting at a "political" gathering, giving a "political" speech, etc (Weber et al., 2015, p. 142).

But neither Aung San Suu Kyi nor her father is just "cause politician" but they live for politics as it is their life's purpose. They both thought democracy as an appropriate system for the country like Myanmar. They encourage people to become "cause politician" to mobilize their political purpose: to build Myanmar with the principles of justice and democracy.

Definition of power. But Weber backs off a bit, and in fact offers a narrower theory of politics: "politics" also means the pursuit for a portion of power, or for influencing the division of power whether it is between states, or between groups of people which the state encompasses (Weber et al., 2015, p. 136).

Max Weber writes "Politics as the leadership or influence exercised by leaders of a political organization; in other words, of a state," and that "Every state is founded on 'Gewalt,' that includes physical force. If there only were social entities which were unaware of the concept of Gewalt as a means [especially with its implications for the use of violence], then the term "state" would cease to exist. And then something would have occurred that we would call anarchy..."

Weber also writes about the relation between the state and physical force. "In the past, various entities-starting with the clan- have known physical force as a normal means. Today, contrary to the past though, we are compelled to say that the state is the only human Gemeinschaft which lays claim to the monopoly on the legitimated use of physical force." (Weber et al., 2015, p. 136)

This definition though points to a conundrum for someone like Aung San Suu Kyi; and in fact it is contrary to nonviolent concepts because as she herself wrote,

Authoritarian governments see criticism of their actions and doctrines as a challenge to combat. Opposition is equated with 'confrontation', which is interpreted as violent conflict. Regimented minds cannot grasp the concept of confrontation as an open exchange of major differences with a view to settlement through genuine dialog. The insecurity of power based on coercion translates into a need 
to crush all dissent. Within the framework of liberal democracy, protest and dissent can exist in healthy counterpart with orthodoxy and conservatism, contained by a general recognition of the need to balance respect for individual rights with respect for law and order (Aung San Suu Kyi. and Aris, 2010, p. 176).

Buried within this passage from her book is the essential problem of what it means to be a nonviolent conviction politician in the liberal democracy as she once dreamed of while under house arrest. How do you maintain a balance between individual rights, respect for law and order, and avoidance of anarchy in a world which is not the liberal democracy and in which the military dominates governments of Myanmar, whether in 1990 or in 2017? How is this balanced with the ethic of responsibility to operate the levers of power in a fashion which brings the greatest benefit to the political body?

The charismatic authority and Myanmar's Gemeinschaft. What proportions of ethical Responsibility and ethical Moral Conviction underlie Aung Sang Suu Kyi's task?

When talking about Aung San Suu Kyi, the enormous influence of her father General Aung San, a national hero of majority Bamar (i.e., ethnic Burmese) people in the country is central. He was assassinated in 1947 after only a brief career as a Myanmar nationalist and military leader. His role is so important that his visage appeared on the country's money in the 1960-1990s, and was eliminated only as his daughter achieved fame as leader of the opposition.

Daw Suu observes Aung San believed in the principles of justice and democracy. "For the people of Burma, Aung San was the man who had come in their hour of need to restore their national pride and honor. As his life is a source of inspiration for them, his memory remains the guardian of their political conscience" (Aung San Suu Kyi. and Aris, 2010, p. 37)

Weber defined the three authorities which justify the legitimacy of the Herrschaft (political dominion/power): the traditional, legal, and charismatic form (Weber et al., 2015, p. 137).

The Herrschaft dominion which emerges by virtue of devotion of obedient people to the personal charisma of "The Leader" [Fuhrer]. This is because the idea of politics as a professional vocation had its highest manifestation in the charisma of a Leader [Fuhrer]. Devotion toward the charisma of the prophet or The Fuhrer during wartime, or the great Demagog in the [Greek] Ecclesia or in Parliament, indicated he was confirmed as the internally called [Fuhrer] of the people. The people submitted to him because they believed in him; they were not forced by custom or laws or coercive power. The charismatic Leader [Fuhrer] lives for his cause, and strives and promotes "his work" (if the Leader [Fuhrer] is more than just someone who, in the blink of an eye, vainly takes advantage of a narrow moment to gain power). [A truly charismatic Leader [Fuhrer] only lives and strives for the calling of politics] (Weber et al., 2015, p. 138).

Aung San (1915-1947) was a truly charismatic leader when Myanmar was under British colonial rule and he is considered the founding father of the nation particularly for the Bamar people. Hundreds of thousands of followers quickly became the followers of Aung San Suu Kyi after her first public speech in Shwedagon Pagoda during 1988 democracy uprising in Myanmar. ${ }^{4}$ People had a huge expectation that Daw Suu would fight against military rule as her father did to the colonial ruler.

Weber explained firstly a career as a politician yields a sense of power. Even in formally modest positions, a politician is aware that they influence the people and that they partake in the exertion of power over them. Finally and most importantly, professional politicians have the feeling that they are lifted above mundane daily routines (Weber et al., 2015, p. 180).

Weber's definition of the sense of power is useful to understand how that power was mobilized in Myanmar. The Aung San Suu Kyi led insurgent political party, the NLD, which fought against the military rule for decades is a coalition of what Weber calls in German Stände, or status groups, comprising the social order. In the case of NLD in 1990 it included primarily ethnic Bamar rising in opposition to the Bamar-dominated military. In this context, the NLD won a landslide victory in 1990 elections after which it was repressed. ${ }^{5}$ After winning another landslide in 2015 elections, the military permitted Aung San Suu Kyi and the NLD to attain limited power as the first civilian government in 60 years. But the constitutional requirement under the 2008 constitution was that the NLD share power with the military which guaranteed the military continued absolute power over the ministries that wielded the tools of coercive violence, i.e., the Defense Ministry, Ministry of Home Affairs, and Ministry of Border Affairs. The NLD gained control of civil administration only recently. ${ }^{6}$ Although Aung Saw Suu Kyi acquired what Weber called "the politically ruling powers (Gewalt)", her government doesn't have full authority to operate the levers of power or physical force.

Both nonviolent concept and limited legitimate power create difficult conundrums for a charismatic leader like Aung San Suu Kyi.

Political suicide: Aung San Suu Kyi's dissonance. Since becoming a stateswoman in 2016, Aung San Suu Kyi is often criticized for silence on different political issues. The case of Rohingya is a real political dilemma for her whether she speaks up or keeps silence. Speaking up on behalf of the Rohingya community will potentially destroy her political standing with the ethnic Bamar who believe the Rohingya are people originally from Bangladesh and were imported as laborers under British colonial rule. Under 1982 Myanmar law they have weak claims to citizenship rights. Aung San Suu Kyi even avoids using the word "Rohingya" and urges international community to use the term "Muslim community in Rakhine State" to put off political tension over a name sensitive to her core Bamar supporters.

Seemingly Daw Suu follows one of the Buddhist Ten Duties of Kings, non-opposition (to the will of the people), in practicing politics: "The royal duty of non-opposition is a reminder that the legitimacy of government is founded on the consent of the people, who may withdraw their mandate at any time if they lose confidence in the ability of the ruler to serve their best interests" (Aung San Suu Kyi. and Aris, 2010, p. 171).

In an interview with the Indian Broadcasting Media, NDTV in 2012, five years before the crisis, Aung San Suu Kyi explained why she is not taking the side of either community, Bamar or Rohingya.

I am not ambivalent about my views on violence. Violence is something I am appalled by completely and condemn completely, but don't forget that violence has been committed by both sides. This is why I prefer not to take sides and also I want to work to reconciliation between these two communities. I am not going to be able to do that if I am going to take sides. (NDTV, 2012).

She is dealing, moreover, with a society in which intense antiRohingya feeling is entrenched across all classes. Buddhist extremists-who are manipulated by the military and who enjoy its tacit support-are already publicly calling her a "Muslim- 
loving whore" (to use one of their printable epithets) (Barany, 2018).

But keeping silence on the Rohingya issue was important to the Bamar population supporting her inside Myanmar. Silence on Rohingya plight is only regarded as an act of political suicide for Aung San Suu Kyi among the Westerners who envisioned her as a democracy and human rights icon. Which constituency would she choose? This is the classic dilemma of the politicians Weber writes of. It appears Aung San Suu Kyi chose her identity as a Myanmar politician, sacrificing her iconic status in the outside world. Daw Suu's ethic of moral conviction follows the Ten Duties of Kings: liberality, morality, self-sacrifice, integrity, kindness, austerity, non-anger, non-violence, forbearance and non-opposition (to the will of the people) (Aung San Suu Kyi. and Aris, 2010, p. 170). She uses her moral character to win the respect and trust of majority people inside the country instead of seeking the applause of the outsiders.

\section{Conclusion}

In an interview earlier in 2017 with the BBC, reporter Fergal Keane Aung San Suu Kyi was asked whether she thought that people in the West had misjudged or mischaracterized her, "expecting you to be this sort of amalgam of Mahatma Gandhi and Mother Teresa, for example, and actually maybe you're closer in your determination and steeliness to someone like [former British Prime Minister] Margaret Thatcher?"

"Well no," she answered. "I am just a politician. I am not quite like Margaret Thatcher, no, but on the other hand, I am no Mother Teresa, either. I have never said that I was. Mahatma Gandhi, actually, was a very astute politician.”

The Nobel Peace Prize gave her an iconic status as a human rights champion and an agent for change. It seems the world looks at her based on the icon status she was given but not as a politician who holds responsibility for the well being of 54 million people. Thus the demon in politics reared its head, and in the 2017 Rohingya crisis Aung San Suu Kyi was "accused of betraying the ideals for which she was once lionized by the world. Her long struggle for freedom has given her unchallenged moral authority. Yet this power, too, she has conspicuously failed to use." (Caryl, 2017).

What "moral authority" given by the Western community to Aung San Suu Kyi was stated in the latest Fact-Finding Mission (FFM) report established by The Human Rights Council:

The state counselor, Aung San Suu Kyi, has not used her de facto position as head of government, nor her moral authority, to stem or prevent the unfolding events, or seek alternative avenues to meet the government's responsibility to protect the civilian population or even to reveal and condemn what was happening (FFM, 2018, p. 391).

The mission also accuses Daw Aung San Suu Kyi and the civilian administration of spreading false and hateful narratives, downplaying the Tatmadaw's wrongdoing, blocking independent investigations-including the Fact Finding Mission's-and overseeing the bulldozing of burned Rohingya villages and the destruction of crime sites and evidence.

But the dominance of the military creates a conundrum for a crusader of non-violent activism like Aung San Suu Kyi. On the other side, she faces conflicts with several ethnic groups including Rohingya in Rakhine State who demand autonomy in a way that may or not be consistent with national interests. Meanwhile, internationalists outside of the country focus exclusively on abstract morally-derived principles of human rights. Aung San Suu Kyi's silence on Rohingya and other issues makes people confused. Is it a sign of "nonviolent reconciliation" with the military? Or is it true that she is the demon portrayed in the international community? Yes and No. Yes, it is a sign of "nonviolent reconciliation" not only with the military but with Rohingyas too. No, she is not a demon but she has her own spiritual and intellectual values shaped by her own environment apart from the political theories and practices she learned from the outside world.Aung San Suu Kyi does not live in a "liberal democracy", so what options does this leave her as a politician? When Aung San Suu Kyi was in opposition from 1988-2015, nonviolent action against authoritarian rule made her become a moral leader in the eyes of international community-as indeed this was the only alternative. She says, "Politics was to do with ethics, it was to do with responsibility, it was to do with service" (NDTV 2012), but as a Stateswoman, "politics" in recent days for her is something to deal with physical force or to take responsibility for its force, which is conflicting with her nonviolent concept. This is the prime ethical paradox and unavoidable pressure in her new vocation.

The journey Aung San Suu Kyi passed through, as an opposition leader and the path she has been leading now as a fullblown politician are totally different, a distinction of which the international humanitarian community seems unaware.

It is undeniable that the role she played as an opposition leader facilitated the democratic transition in Myanmar. But her role was not bigger than a passionate "volunteer" in country's politics at that time. Weber wrote that "anybody who practices politics striving for power, either power as an instrument to pursue a goal - a goal that can be idealistic or selfish-or to enjoy power for the sake of power itself because it gives (pleasurable) feelings of prestige" (Weber et al., 2015, p. 137). Daw Suu seems to enjoy feelings of prestige as Mother Suu, as a mother of the nation. As Weber said, "Politics is like slowly but forcefully drilling holes in hardwood boards, and that with passion and, at the same time, with a sense of proportion" (Weber et al., 2015, p. 198).

Aung San Suu Kyi inherited the sense of responsibility as the political legacy of her father Aung San and the Buddhist view of kingship as the moral legacy. Certainly politics is her vocation but not exactly the way Weber defined it but in a way she was shaped by "the spiritual and intellectual values" as she stated from her own environment. When journalists often asked her a question about how she wants people to recognize her, she simply said "I will be satisfied if most people regard me as someone who's done her job. That's all I want" (Suu Kyi, 2016). In spite of all the hardships, politics means for her just "a job". In fact Politics is a vocation for Aung San Suu Kyi.

\section{Data availability}

Data sharing is not applicable to this paper as no datasets were generated or analyzed.

Received: 6 November 2018 Accepted: 29 April 2019

Published online: 14 May 2019

\section{Notes}

1 The choice of country name, Burma or Myanmar, was a serious debate in the international community in the past because the term "Myanmar" was given by the military regime and the country name was changed without taking people's consensus. Many international organizations and media strongly opposed using the term "Myanmar" for not showing support to the military regime. The debate is over today as the country has shifted from the military rule to the elected civilian rule. The ruling government still keeps the official name as "Myanmar" as it is an official name recognized by the UN and international governments. In this paper, I am going to use the term "Myanmar" because it is internationally recognized and it's a literary form for 
writing. If the papers I cite for this study use the country name "Burma", I will keep it as it is.

2 Daw is a title used before a surname and a polite way of referring to a woman in Myanmar. In this paper I will use "Daw Suu" to refer to Aung San Suu Kyi.

3 Bamar is a dominant ethnic group, which forms $68 \%$ of country population. Myanmar officially recognizes 135 ethnic groups.

4 On August 8, 1988, a nationwide strike involving hundreds of thousands of students, Buddhist monks, civil servants, and ordinary citizens led to simultaneous protests in cities and towns across Myanmar, calling for a transition to democracy and an end to military rule. The size and scale of what became daily protests surprised the government, which then ordered troops to suppress the protests on Sept 18, 1988. Troops fired on peaceful protesters, killing and wounding hundreds. While many fled, some protesters fought back with Molotov cocktails, swords, poisoned darts, and sharpened bicycle spokes, killing some policemen and other officials. (Human Rights Watch, 2013)

5 The NLD did not win another election until the by-elections 2012. The military in 2008 promulgated a new Constitution which preserved substantial military power indefinitely. In the 2015 national elections the NLD nevertheless won majority of the vote.

6 The General Administration Department (GAD) was transferred to the civiliancontrolled Ministry in December 2018. Previously GAD was under the Ministry of Home Affairs and was directly controlled by the military.

\section{References}

Aung San of Burma (n.d.) Aung San Burma. http://aungsan.com/quotes3.htm Accessed 14 March 2019

Aung San SK, Aris M (2010) Freedom from fear: and other writings. Penguin Books, London

Barany Z (2018) Burma: Suu Kyi’s Missteps. J Democr 29:5-19

Caryl C (2017) No one has fallen further than Aung San Suu Kyi. Wash. Post

Egreteau, R., \& Robinne, F. (2015). Metamorphosis. Singapore: NUS Press

FFM (2018) Report of the detailed findings of the Independent International FactFinding Mission on Myanmar (No. A/HRC/39/CRP.2)

Houtman, G. (1999). Mental culture in Burmese crisis politics: Aung San Suu Kyi and the National League for Democracy. Tokyo: Institute for the Study of Languages and Cultures of Asia and Africa (ILCAA), Tokyo University of Foreign Studies

Myat MM (2011) The Lady speaks

NDTV (2012) My farewell message for my husband was too late, says Aung San Suu Kyi to NDTV

Siddique H (2013) Burma sectarian violence motivated by fear, says Aung San Suu Kyi State Counsellor (2017) Myanmar does not fear world scrutiny. Glob. New Light Myanmar
Suu Kyi AS (2016) A Long Way Panglong, 1st edn. Creative Media House, Yangon Tambiah SJ (1976) World conqueror and world renouncer: a study of Buddhism and Polity in Thailand against a historical background. Cambridge University Press, Melbourne

The Nobel Prize (2012) Nobelprize.org. https://www.nobelprize.org/nobel_prizes/ peace/laureates/1991/kyi-lecture_en.html Accessed 31 Dec 2017

Transcript of ASSK interview (1994) (n.d.) Burma Library. http://www. burmalibrary.org/reg.burma/archives/199405/msg00060.html

Weber, Max, Tony Waters, Dagmar Waters (1919/2015) "Politics as Vocatoin" in Weber's Rationalism and Modern Society: new translations on politics, bureaucracy, and social stratification

Wintle J (2008) Perfect hostage: a life of Aung San Suu Kyi. Arrow, London

Zollner H-B, Ebbighausen R, Bansal V (2018) The daughter: a political biography of Aung San Suu Kyi

\section{Acknowledgements}

Thanks go to Tony Waters who assisted with the editing of the text.

\section{Additional information}

Competing interests: The author declares no competing interests.

Reprints and permission information is available online at http://www.nature.com/ reprints

Publisher's note: Springer Nature remains neutral with regard to jurisdictional claims in published maps and institutional affiliations.

(c) (i) Open Access This article is licensed under a Creative Commons Attribution 4.0 International License, which permits use, sharing, adaptation, distribution and reproduction in any medium or format, as long as you give appropriate credit to the original author(s) and the source, provide a link to the Creative Commons license, and indicate if changes were made. The images or other third party material in this article are included in the article's Creative Commons license, unless indicated otherwise in a credit line to the material. If material is not included in the article's Creative Commons license and your intended use is not permitted by statutory regulation or exceeds the permitted use, you will need to obtain permission directly from the copyright holder. To view a copy of this license, visit http://creativecommons.org/ licenses/by/4.0/.

(C) The Author(s) 2019 